SUSTAINABLE FORESTRY

COLLECTION 65-66, 2012
ODRŽIVO ŠUMARSTVO

ZBORNIK RADOVA 65-66, 2012

UDK $630 * 232.322 .41: 582.628$ Juglans regia $\mathrm{L} .=111$

Original scientific paper

\title{
THE EFFECT OF APPLICATION OF DIFFERENT NUTRITION PREPARATIONS ON HEIGHT INCREMENT OF WALNUT (Juglans regia L.) SEEDLINGS
}

\author{
Tatjana ĆIRKOVIĆ-MITROVIĆ, Vladan POPOVIĆ, \\ Ljiljana BRAŠANAC-BOSANAC, Ljubinko RAKONJAC, Aleksandar LUČIĆ ${ }^{1}$
}

\begin{abstract}
Providing of quality planting material which takes root well after planting, resistant to diseases, pests, stress (drought, extreme temperature, etc.) and grows well in cultures is one of the strategic and preferential tasks of modern forestry. Walnut is a fruit tree important as a founder of various varieties and hybrids, and as a rootstock for high-yielding varieties. It is also of great importance because of high nutritional value of fruit and high quality of stem. For that reason this species has to be introduced into the existing ecosystem and used for afforestation of different habitats.

The paper presents results of research on the effect of the controlled decomposing fertilizer Osmocote Exact ${ }^{\circledR}$, mineral NPK fertilizer Florin 2 and microbiological preparation Bactofil ${ }^{\mathbb{B}}$ B 10 on height increment of walnut seedlings. Data analysis was performed by relevant procedures using statistical software packages (SPSS Statistics 17.0). Comparative analysis of height increment of seedlings treated with these preparations and height increment of untreated seedlings, as well as a simple way of application of these preparations by adding them to the substrate, will show the justification of direct application of these types of fertilizers and microbiological preparation in mass production of high quality planting material.
\end{abstract}

Key words: walnut, mineral fertilizers, microbiological preparation, height increment.

\footnotetext{
${ }^{1}$ Institute of Forestry, Belgrade, Kneza Viseslava No 3, Serbia

E-mail: tanjacirk@yahoo.com
} 


\title{
UTICAJ PRIMENE RAZLIČITIH PREPARATA ISHRANE NA VISINSKI PRIRAST SADNICA ORAHA (Juglans regia L.)
}

\begin{abstract}
Obezbeđivanje sadnog materijala koji se dobro prima nakon sadnje, otpornog na bolesti, štetočine, stres (suša, ekstremne temperature, $i d r$.) $i$ dobro raste $u$ kulturama, jedan je od strateških i prioritetnih zadataka savremenog šumarstva. Orah je voćkarica značajna kao rodonačelnik različitih sorti i hibrida i kao podloga za kalemljenje visokorodnih sorti. Takođe je od velikog značaja zbog visoke hranljive vrednosti plodova $i$ visoko kvalitetnog debla. Zato ovu vrstu treba unositi u postojeće ekosisteme i njome pošumljavati različita staništa.

U radu će biti prikazani rezultati istraživanja uticaja kontrolisano razlagajućeg đubriva Osmocote Exact ${ }^{\mathbb{B}}$, mineralnog NPK đubriva Florin 2 i mikrobiološkog preparata Bactofil ${ }^{\mathbb{R}}$ B 10 na visinski prirast sadnica oraha. Obrada podataka izvršena je odgovarajućim procedurama korišćenjem programskih statističkih paketa (SPSS Statistics 17.0). Komparativna analiza visinskog prirasta sadnica tretiranih ovim preparatima i visinskog prirasta netretiranih sadnica, kao $i$ jednostavan način primene navedenih preparata dodavanjem u supstrat, ukazuje na opravdanost direktne primene ovih tipova dubriva $i$ mikrobiološkog preparata u masovnoj proizvodnji visokokvalitetnog sadnog materijala.
\end{abstract}

Key words: orah, mineralna đubriva, mikrobiološki preparat, visinski prirast.

\section{INTRODUCTION}

In Serbia within natural, forest ecosystems, is noted the presence of 122 fruit trees, grouped into 23 families and 38 genera. Range of many fruit trees has declined alarmingly in the past 50 years and production of seedlings and their introduction into existing forests as well as afforestation of bare land contributes to the improvement of natural biological wealth of Serbia.

Initial planting material is of major importance for the success of afforestation. Using of poor quality planting material increases the costs of establishment and maintenance of cultures, while the success of afforestation is diminished (Oliet, J. A. et al., 2009). Previous experience in afforestation proved that a good selection of species and planting material characteristics (development of root system, resistance to temperature extremes, etc.) are very important for afforestation and must be taken into consideration.

Certain scientific researches have proved that application of nutrition preparations in contemporary seedling production represents not only an additional source of nutrients, but also a powerful mean and important factor in production of high-yielding planting material for various purposes. A nutrition system of woody plants in juvenile development phase should be planned on the basis of contemporary developments in the field of production of various types of fertilizers and experimental data obtained as a result of established experiments. The selection of type, quantity and time of use of a fertilizer depends primarily on the biological characteristics of plants, soil condition, plant development stadium as well as the characteristics of the fertilizer itself (Tucović, A., Simić, Z., 2002).

Taking into account the fact that the mineral nutrition is the most effective method to improve quality and increase biomass production in forest trees and the 
forest fruit trees, too, the scientific objective of this research was to select, on the basis of height increment of walnut seedlings treated with three different types of nutrition preparations, the preparation that has the biggest influence on height increment of seedlings and thus contributes to the proper development and optimal quality of seedlings. An easy way to apply the nutrition preparation by adding it to the substrate certainly would justify its use in the mass production of high quality planting material.

\section{MATERIAL AND METHOD}

For the purpose of research and analysis of heights and height increment during vegetation period of walnut seedlings and monitoring the effects of various types of fertilizers, a sample plot was established in the seedling nursery of the Institute of Forestry in Belgrade. The nursery is located at $20^{\circ} 27,44$ " east longitude and $44^{\circ} 49^{\prime} 14^{\prime \prime}$ north latitude, and the altitude of 95 meters.

By processing of data of Meteorological Service of Serbia for Weather station in Belgrade for the period from 1980 to 2009, we have obtained the average monthly air temperature and average monthly and annual precipitation for the site where the experiment was set up. Based on the obtained data we got and the average monthly amount of precipitation and average monthly temperature in the vegetative period.

The walnut seed collected in 2010 was used for establishment of sample plot. Due to dormancy of embryo, the walnut seed was held in a wet stratification from November 2010 to the end of March 2011 (at the temperature $3-5{ }^{\circ} \mathrm{C}$ ). The sowing was performed in April 2011, in rows, 6 pieces per linear meter, at the depth of $8 \mathrm{~cm}$.

The seed was planted in Tref TPS fine brown substrate, produced by TREF Group, Jiffy product international AS from Norway. For its production is used peat moss from Estonia which does not contain weeds, dirt and pathogens, of fraction $<8 \mathrm{~mm}$ and $\mathrm{pH} 5.8( \pm 0,3)$, and represents a mixture of peat moss and perlite in a 9:1 ratio, while peat moss is a mixture containing $70 \%$ of white peat moss and $30 \%$ of black peat moss.

The analysis of height growth was performed on seedlings that were not treated with nutrition preparations, so-called 'control seedlings' (in experiment labeled with number 1), as well as on seedlings that were treated with three types of fertilizers: a controlled release fertilizer Osmocote ${ }^{\circledR}$ Exact Standard 5-6 M (treatment labeled in experiment with number 2), a microbiological preparation Bactofil $^{\mathbb{B}}$ B 10 (treatment labeled in experiment with number 3) and a complex NPK mineral fertilizer Florin 2 (treatment labeled in experiment with number 4).

Osmocote $^{\circledR}$ Exact consists of fine NPK granules and contains microelements in traces and additional magnesium. Each granule of size $2-4 \mathrm{~mm}$ is covered with an organic semi-permeable coating, a membrane of biodecomposable resin produced from plant oils. A granule enables longer retention of nutrients and a more even plant nourishment, without the possibility of rinsing. The nutrients are extracted from granules by osmosis, i.e., the plant pumps them with the aid of water. Osmocote ${ }^{\circledR}$ Exact Standard 5-6 $M$ has a mark $15+9+12+2 \mathrm{MgO}+$ micro-elements, that denotes a percentage content of nitrogen, 
phosphorus, potassium, magnesium and micro-elements necessary for plant growth and development. Nitrogen accounts for $15 \%, \mathrm{P}_{2} \mathrm{O}_{5}$ accounts for $9 \%$, while $\mathrm{K}_{2} \mathrm{O}$ accounts for $12 \%$. $\mathrm{MgO}$ accounts for $2 \%$, the total Iron accounts for $0.45 \%, \mathrm{Mn}$ accounts for $0.06 \%, \mathrm{Zn}, \mathrm{B}$ and Mo account for $0.020 \%$ each, while $\mathrm{Cu}$ accounts for $0.055 \%$. Life span of this fertilizer is $5-6$ months at the temperature of $21{ }^{\circ} \mathrm{C}$. At higher temperatures dissolution of nutrients is more rapid and slower at lower temperatures, which suits the plant needs for nutrients. Salt level, $\mathrm{Ph}$, activities of micro-organisms and quality of water or rain do not influence dissolution of nutrients, the only relevant factor is the temperature, which makes Osmocote ${ }^{\mathbb{B}}$ Exact very reliable in use.

Bactofil is a micro-biological fertilizer that contains ten most important sorts of soil bacteria, which enable optimum soil conditions for plant growth and development. Bacteria perform an irreplaceable role in sustainment of soil fertility by binding nitrogen from air and transforming it into a form that is easily accessible to plants. Furthermore, they increase phosphorus and potassium reserves in soil and help with decomposition of organic matter. Bacteria in Bactofil preparation are: Azotobacter vinelandii, Azospirilium brasilense, Azospirilium lipoferum, Bacillus, Pseudomonas, Bacillus subtilis, Bacillus polymyxa, Bacillus cirkulans, Streptomyces albus, Micrococcus roseus. By its addition to the substrate, Bactofil directly influences the intensity of humification and mineralisation process.

Florin 2 NPK 15:15:15, a complex NPK mineral fertilizer, contains $15 \%$ of nitrogen $\left(6.5 \%\right.$ nitrate and $8.5 \%$ ammonium), $15 \%$ of phosphorus oxide $\mathrm{P}_{2} \mathrm{O}_{5}$ (soluble in $2 \%$ citric acid and $9 \%$ soluble in water) and $15 \%$ of potassium oxide $\mathrm{K}_{2} \mathrm{O}$ (soluble in water). NPK fertilizer has the widest application in Serbia, primarily due to favorable price.

The analysis of walnut seedlings involved the study of the above-ground part heights and comparison of similarities and differences depending on treatment with the above-mentioned nutrition preparations, with the comparison of obtained results with the results of the control, non-treated seedlings.

Data processing was performed by relevant procedures using statistical software packages (SPSS Statistics 17.0). The estimate of statistical significance of different variation factors of the monitored characteristics of walnut seedlings was performed by application of variance analysis. By models of estimation of significance of various factors' contribution to the total variation of characters, a statistical significance of the variation sources was described depending on the type of applied fertilizer (variation contingent upon the type of fertilizer used in the experiment).

The statistical justification of the differences between mean values of the analysed morphometric characteristic was determined by the LSD test with a probability of $95 \%$. 


\section{RESULTS AND DISCUSSION}

\section{Climatic characteristics}

The average air temperature is $12.5{ }^{\circ} \mathrm{C}$, while the average temperature in vegetation period is $19.2^{\circ} \mathrm{C}$. The temperature reaches the lowest values in January (the average value for this month is $1.3{ }^{\circ} \mathrm{C}$ ), while the hottest month is July with $22.9^{\circ} \mathrm{C}$.

The total annual precipitation sum is $692 \mathrm{~mm}$, while in the vegetation period it amounts to $393 \mathrm{~mm}$, which is $57 \%$ of the total annual amount.

High amount of precipitation in the vegetation period is of particular importance for development, growth and increment of all plant species. The rainiest month is June, while the lowest amount of precipitation is recorded in February. A secondary precipitation maximum, with lower values, is reached in December, while a secondary minimum occurs in October (Ćirković-Mitrović, T. et al. 2012, 2012a).

\section{Variation of height increment of one-year-old walnut seedlings contingent upon treatment by various nutrition preparations}

The statistical analysis of length of the walnut seedling above-ground part contingent upon the treatment by different preparations indicates that after a more or less uniform increase in height at the beginning of the vegetation period comes to an increasing of differentiation of this morphometric marker in plants treated with Osmocote. (Table 1).

After intense height increment at the beginning of the vegetative period (until May-June) in all treatments, this morphometric parameter in seedlings treated with Osmocote and Bactofil began to show a declining trend. In seedlings treated with Bactofil the height increment decreases abruptly, while in the seedlings treated with Osmocote the height increment by the end of the vegetative period retains high values and statistically differs significantly from height increment of seedlings from other two treatments and control seedlings. In control seedlings and those treated with Florin the current height increment culminates in period of JuneJuly and then abruptly decreases. At the end of the vegetation period, before the start of vegetative rest, the height increment of all seedlings is uniform, with no significant differences. The curves of height development also indicate these trends (Table 1, Graph 1). In August starts the differentiation of heights of seedlings treated with Osmocote and control seedlings, and by the end of the vegetation period this parameter is significantly different compared to the heights of seedlings treated with Bactofil and Florin. (Table 1, Graph 1). 
Table 1. Method: 95.0 percent LSD

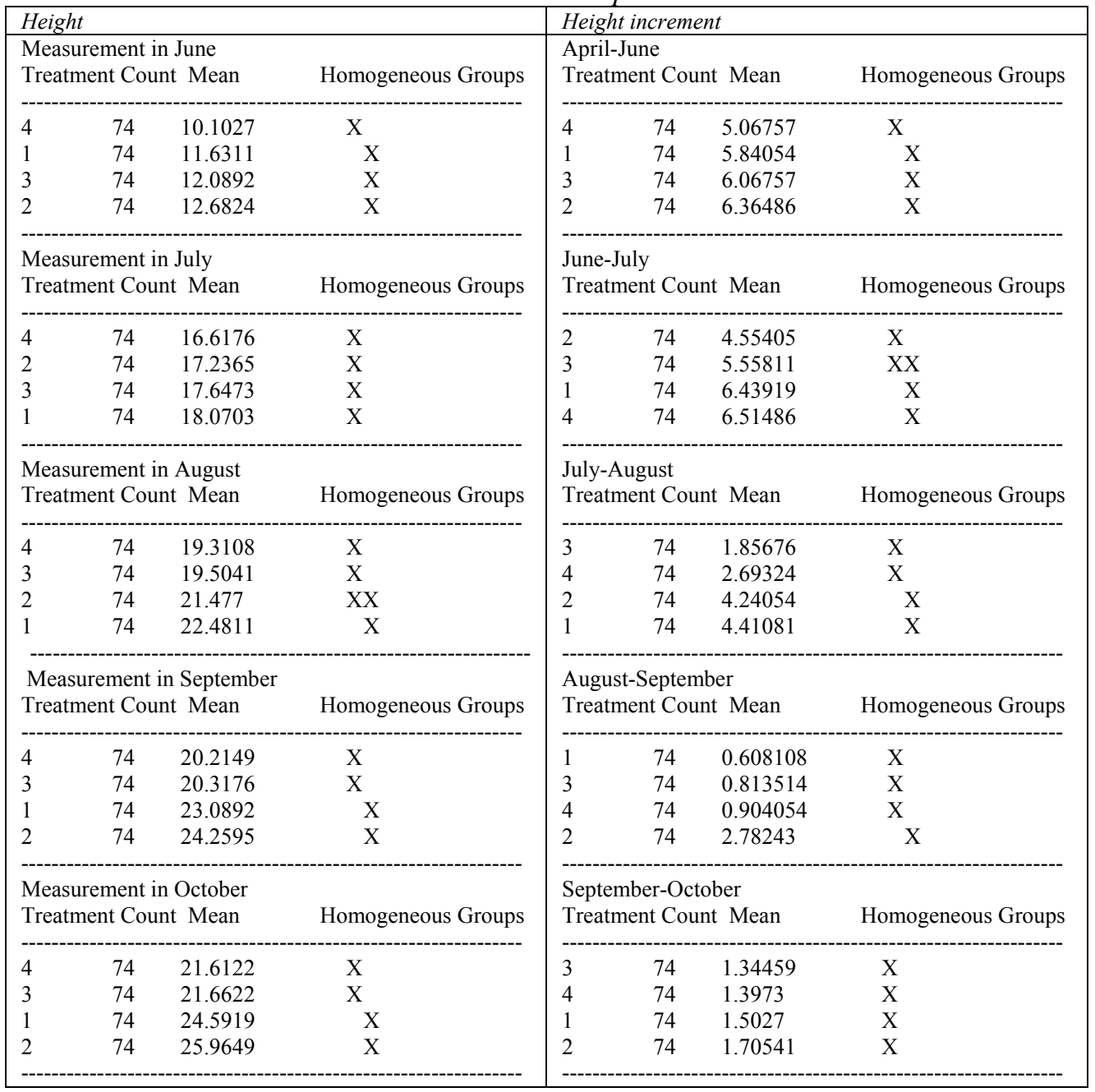

Table 2. Summary statistics for the height growth of walnut (Juglans regia L.) seedlings at the end of the vegetation period

\begin{tabular}{|c|r|r|r|r|r|r|r|}
\hline Treatment & Count & Average & Variance & St. deviation & Minimum & Maximum & Range \\
\hline 1 & 74 & 24.5919 & 39.4687 & 6.28241 & 13.4 & 40.0 & 26.6 \\
\hline 2 & 74 & 25.9649 & 94.1166 & 9.70137 & 12.5 & 55.0 & 42.5 \\
\hline 3 & 74 & 21.6622 & 39.3079 & 6.2696 & 14.0 & 46.0 & 32.0 \\
\hline 4 & 74 & 21.6122 & 71.8835 & 6.2696 & 9.0 & 45.3 & 36.3 \\
\hline & 296 & 23.4578 & 64.1344 & 8.0084 & 9.0 & 55.0 & 46.0 \\
\hline
\end{tabular}




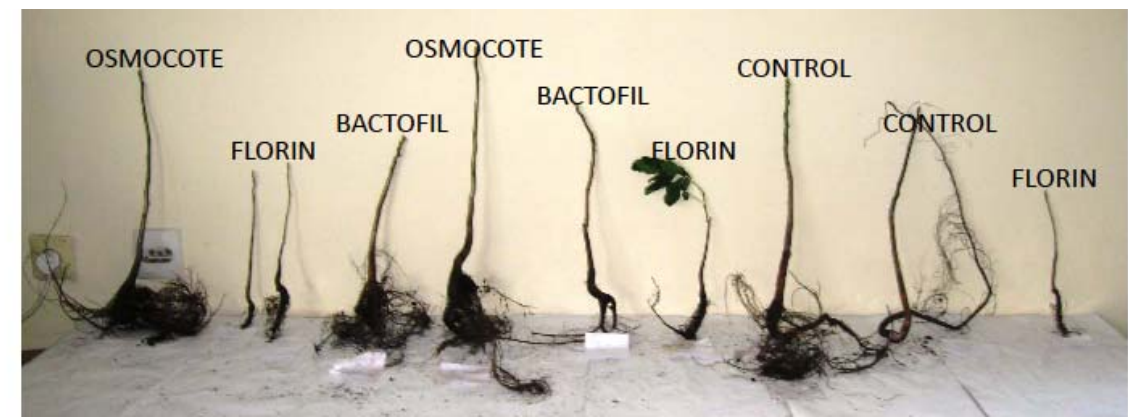

Picture 1. Walnut seedlings treated with Osmocote, Florin, Bactofil and control seedlings

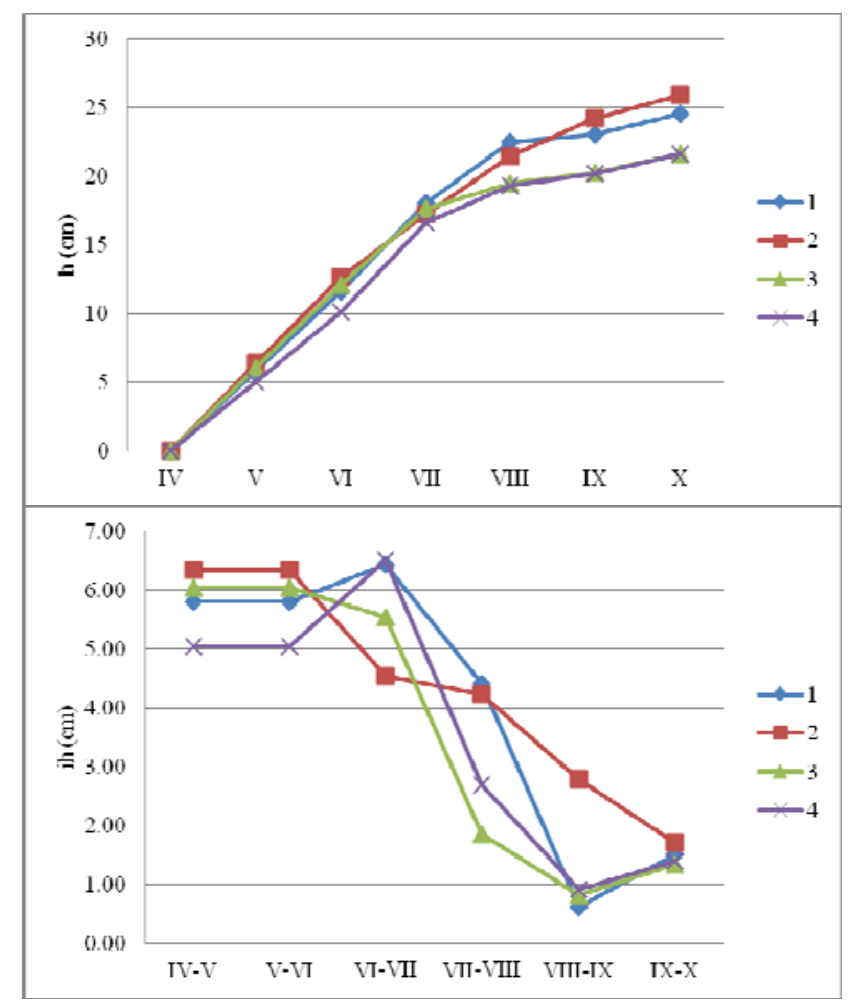

Graph 1. Development of height and height increment of walnut (Juglans regia L.) seedlings during the vegetation period

At the end of the vegetation period, the seedling with the absolute smallest height was measured in seedlings treated with Florin and the seedling with the absolute largest height was measured in seedlings treated with Osmocote. The smallest seedling has height of $9.0 \mathrm{~cm}$, and the highest seedling has height of 55.0 $\mathrm{cm}$ (amplitude is $46.0 \mathrm{~cm}$ ). Also, the largest average height of $25.96 \mathrm{~cm}$ have seedlings treated with Osmocote. The smallest average height of $21.61 \mathrm{~cm}$ have seedlings treated with Florin (Table 3).

Based on the obtained results it can be concluded that the nutrition preparation Osmocote is suitable for the production of walnut seedlings. That 
nutrition with nitrogen, phosphorus and potassium can influence increase of some growth parameters such as height, have shown researches in Serbia: Đukić, M. et al. (2004) with Spruce seedlings and different types of substrates, Šijačić-Nikolić, M. (2006) with Beech seedlings treated with Osmocote. Komlenović, N. (1997) also finds a positive impact of fertilizer Osmocote on the production of coastal pines in Croatia. In Turkey, the Ash (Fraxinus) seedlings in the first year respond positively to treatment with NPK fertilizers (Cicek, E. et al., 2010).

\section{CONCLUSION}

Based on the obtained results it can be concluded that used nutrition preparations differently affect the height of walnut seedlings. Control seedlings and seedlings treated with the slowly decomposing mineral fertilizer Osmocote show better results than those treated with microbiological preparation Bactofil and NPK mineral fertilizer Florin.

Controlled decomposing fertilizer Osmocote Exact ${ }^{\circledR}$ positively affects the development of seedlings stimulating the development of seedlings height which is of particular importance if one takes into account that height, along with root collar diameter, is one of the most important morphological criteria of quality of deciduous seedlings (Stilinović, S. 1987). Being the slowly decomposing fertilizer, Osmocote exerts a positive impact on seedling development, as the effect it produces coincides with the duration of the vegetation period.

An easy way of application by adding fertilizer directly to the substrate during its preparation, controlled decomposition that follows the needs of the plant and a relatively long period of activity speak in favor of justification of application of this fertilizer in mass production of high quality planting material for different purposes.

\section{Acknowledgement}

The research is financed by the Ministry of Science and Technological Development of the Republic of Serbia, Project TR 31070 "The development of technological procedures in forestry with a view to an optimum forest cover realisation" (2011-2014).

\section{REFERENCES}

Cicek, E., Yilmaz F., Yilmaz, M. (2010): Effect of N and NPK fertilizers on early field performance of narrow-leaved ash, Fraxinus angustifolia. Journal of Environmental Biology, 31, 109-114

Đukić, M., Đunisijević, D., Grbić, M., Skočajić, D. (2004). Effect of nourishment on oneyear-old spruce seedling growth on different substrates, The Faculty of Forestry Herald, Belgrade, 2004, no 89, pages 103-113.

Ćirković-Mitrović, T., Brašanac-Bosanac, Lj., Popović, V. (2012): Effect of fertilizer application on morphological characteristics of walnut (Juglans regia L.) juvenile seedlings, 
International Conference on BioScience: Biotechnology and Biodiversity - Step in the Future, The Forth Joint UNS-PSU Conference, Novi Sad, June 18-20, 2012., Book of Abstracts, p. 94.

Ćirković-Mitrović, T., Popović, V. Brašanac-Bosanac, Lj., Lučić, A., Rakonjac Lj. (2012): The effect of application of mineral fertilizers and microbiological preparation on radial growth of walnut (Juglans regia L.) seedling, International Conference: Forestry science and practice for the purpose of sustainable development of forestry - 20 years of the Faculty of Forestry in Banja Luka. Banja Luka, $1^{\text {th }}-4^{\text {th }}$ November, 2012. Book of Abstracts, p. 93.

Komlenović, N. (1997): Application of slow release fertilizers in production of Mediterranean pine seedlings, Forestry review No. 1-2, CXXI (1997), 19-27

Oliet, J., A., Planelles, R., Artero, F., Valverde, R., Jacobs, D., F., Segura, M., L. (2009). Field performance of $\mathrm{P}$. halepensis planted in Mediterranean arid conditions: relative influence of seedling morphology and mineral nutrition. New Forest, 37(3): 313-331.

Stilinović, S. (1987): Seedlings production of forest and ornamental trees and shrubs, Belgrade University, Belgrade, pp. 1-454.

Šijačič-Nikolić, M., Vilotić, D., Radošević, G., (2006): Effect of controlled decomposing fertilizers on morpho-anatomical characteristics one-year-old beech seedlings, Forestry, no $1-2,149-156$.

Thompson, B. (1982). Why fall fertilize. Southern Oregon State College, Ashland, 85-91.

Tucović, A., Simić, Z. (2002). Plant Nourishment, Institute for School Books and Teaching Aids, Belgrade, 1-122.

\title{
UTICAJ PRIMENE RAZLIČITIH PREPARATA ISHRANE NA VISINSKI PRIRAST SADNICA ORAHA (Juglans regia L.)
}

\author{
Tatjana Ćirković-MITROVIĆ, Vladan POPOVIĆ, Ljiljana BRAŠANAC-BOSANAC, \\ Ljubinko RAKONJAC, Aleksandar LUČIĆ
}

\section{Rezime}

Uzimajući u obzir činjenicu da je mineralna ishrana najefikasniji metod za poboljšanje kvaliteta i povećanje produkcije biomase kod šumskog drveća, samim tim i šumskih voćkarica, naučni cilj ovih istraživanja bio je da se na osnovu porasta visina sadnica oraha tretiranih sa tri različita tipa preparata ishrane odabere onaj preparat, čiji je uticaj na visinski razvoj sadnog materijala bio najveći i time doprineo pravilnom razvoju i optimalnom kvalitetu sadnica.

$\mathrm{Na}$ osnovu dobijenih rezultata konstatovano je da korišćeni preparati ishrane različito utiču na visinu sadnica oraha. Kontrolne sadnice i sadnice tretirane spororazlagajućim mineralnim đubrivom Osmocote pokazale su bolje rezultate u odnosu na one tretirane mikrobiološkim preparatom Bactofil i NPK mineralnim đubrivom Florin.

Kontrolisano razlagajuće đubrivo Osmocote Exact ${ }^{\circledR}$ pozitivno utiče na razvoj sadnica stimulišući razvoj visina sadnica, što je od posebnog značaja ako se ima u vidu da je visina, uz prečnik u korenovom vratu, jedan od najvažnijih morfoloških kriterijuma kvaliteta lišćarskih sadnica (Stilinović, S. 1987). Kao spororazlagajuće đubrivo, Osmocote takođe ima značaj, jer se dužina njegovog delovanja na biljke poklapa sa dužinom trajanja vegetacionog perioda. 
